\title{
The Random Inactivation of the X Chromosome Carrying the Defective Gene Responsible for X-linked Hyper IgM Syndrome (X-HIM) in Female Carriers of HIGM1
}

\author{
Diane Hollenbaugh, Lynne H. Wu," Hans D. Ochs, ${ }^{\star}$ Shigeaki Nonoyama, ${ }^{\star}$ Laura S. Grosmaire, Jeffrey A. Ledbetter, \\ Randolph J. Noelle, ${ }^{\ddagger}$ Harry Hill,, and Alejandro Aruffo \\ The Bristol-Myers Squibb Pharmaceutical Research Institute, Seattle, Washington 98121; * Department of Pediatrics, University of \\ Washington, Seattle, Washington 98195; ${ }^{\ddagger}$ Department of Microbiology, Dartmouth Medical School, Lebanon, New Hampshire 03756; \\ and ${ }^{\S}$ Department of Pediatrics, University of Utah, Salt Lake City, Utah 84132
}

\begin{abstract}
The molecular origin of $\mathrm{X}$-linked hyper IgM syndrome has recently been identified as a defect in the ligand of CD40, gp39, a protein expressed on the surface of activated $T$ cells. The availability of detailed pedigrees for three families with affected males allowed assessment of the random or nonrandom nature of the inactivation of the defective $X$ chromosome as well as a determination of the origin of the mutation. $X$ chromosome inactivation was studied because of the relevance to the ability to detect carriers of HIGM1 and the potential for phenotypic effect in the carriers. Using immunostaining, PCR, and DNA sequencing, we found that the defective gene for gp39 is not selectively inactivated. Even in the presence of extremely skewed inactivation, normal levels of serum Ig were found. In carriers in which the defective gene is predominantly expressed, staining alone revealed the carrier status reliably while cloning and sequencing of the cDNA was necessary when the normal gene was predominantly expressed. Unlike some other $\mathrm{X}$-linked defects where extreme Lyonization may lead to disease, a small population of cells expressing the wild-type gp39 is sufficient to maintain normal humoral immunity and prevent the clinical symptoms of X-HIM. (J. Clin. Invest. 1994. 94:616-622.) Key words: Lyonization - X-linked hyper IgM syndrome • carrier detection • CD40 • gp39
\end{abstract}

\section{Introduction}

$\mathrm{X}$-linked hyper IgM syndrome (X-HIM) ${ }^{1}$ is a primary immunodeficiency disorder characterized by hypogammaglobulinemia and recurrent bacterial infections. Affected males have normal levels of circulating $\mathrm{T}$ and $\mathrm{B}$ cells, normal to elevated levels of serum IgM, low levels of IgG, and nondetectable levels of IgE or IgA. As a result of the impaired immune response, affected males are susceptible to bacterial and opportunistic infections,

Address correspondence to Diane Hollenbaugh, BMS-PRI, 3005 First Ave, Seattle WA 98121.

Received for publication 18 January 1994 and in revised form 14 March 1994.

1. Abbreviations used in this paper: X-HIM, X-linked hyper IgM syndrome; XLA, X-linked agammaglobulinemia.

J. Clin. Invest.

(c) The American Society for Clinical Investigation, Inc.

0021-9738/94/08/0616/07 \$2.00

Volume 94, August 1994, 616-622 generally beginning at the end of the first or early in the second year of life. The clinical manifestations of X-HIM include recurrent upper respiratory tract infections, pneumonia, diarrhea, otitis media, occasional lymphoid hyperplasia, and frequent neutropenia. In addition, it appears that affected males, as a group, are unusually susceptible to Pneumocystis carinii. Though intravenous immunoglobulin infusions are effective, $X-H I M$ patients may succumb to opportunistic infection early in life or to lymphomas or other malignancies during childhood or early adulthood (1).

The molecular basis of X-HIM has recently been shown to result from defects in the $\mathrm{T}$ cell surface protein gp39. Studies designed to elucidate the role of lymphocyte cell surface proteins in T cell-B cell interactions have previously led to the identification and characterization of the gp39/CD40 ligand receptor pair as important in B cell proliferation and antibody isotype switching (2-4). Gp39 (CD40L, Trap) is a type II membrane glycoprotein expressed on the surface of T cells 6-8 h after activation (5-8). CD40 is a type I membrane glycoprotein (9) constitutively expressed by B cells (2), monocytes (10), follicular dendritic cells, basal and thymic epithelial cells (11, 12), and some tumor-derived cell lines (13). Stimulation of the CD40 receptor with anti-CD40 monoclonal antibodies (mAbs) or recombinant gp39 in conjunction with IL-4 or IL-10 results in B cell proliferation and the production of $\operatorname{IgE}$ or $\operatorname{IgA}$, IgG and IgM immunoglobulin isotypes, respectively $(3,14-18)$ (S. Nonoyama, unpublished observations). Stimulation of CD40 on monocytes and thymic epithelial cells modulates cytokine secretion by these two cell types (10).

Two independent approaches led to the determination that defects in the gp39 gene are the molecular basis for X-HIM. In the first approach, the role of the gp39/CD40 interaction was examined in several primary immunodeficiency disorders, including common variable immunodeficiency (CVI), X-linked agammaglobulinemia (XLA) and X-HIM. These studies demonstrated that peripheral blood $\mathrm{T}$ cells from X-HIM patients fail to express detectable levels of functional gp39 protein following in vitro activation, yet these cells express levels of mRNA encoding gp39 within the normal range. Sequencing of gp39 cDNAs obtained from X-HIM patients showed that they contained point mutations. It was subsequently shown that these point mutations abolished the ability of gp39 to bind to CD40 and drive $B$ cell proliferation and isotype switching (15). In a different approach, the gene encoding gp39 was found to be localized to the same area of the $\mathrm{X}$ chromosome as the gene responsible for X-HIM. This initiated an examination of the gp39 protein levels expressed by activated $T$ cells from patients with X-HIM. The observation that the $T$ cells from affected patients expressed no functional gp39 led to DNA sequencing 
experiments and the demonstration of mutations in the gp39 gene in individuals with X-HIM (19-22).

Knowledge of the genetic basis of HIGM1 allows examination of the possibility of nonrandom $\mathrm{X}$ chromosome inactivation in female carriers and sets the stage for the development of methodologies for the detection of female carriers and prenatal diagnosis. Here we describe the detailed pedigree analysis of three families with affected males, which allowed us to identify five female carriers of HIGM1. We investigated the inactivation of the defective $\mathrm{X}$ chromosome in these female carriers by immunofluorescence staining, to identify the fraction of in vitro activated $\mathrm{T}$ cells expressing functional gp39, and by DNA sequencing of multiple independent cDNA clones obtained by PCR.

\section{Methods}

Patients and their families. C.D., the only affected male in Family 1, is a 15 -yr-old boy with a history of frequent bacterial infections since infancy, moderately elevated IgM, low IgG, and absent IgA. His halfsister, mother, and two maternal uncles are healthy and alive. The four brothers of his maternal grandmother were healthy through adulthood; two are still alive.

J.W., the second son of a healthy mother, developed $P$. carinii during infancy and subsequently had recurrent bacterial infections. His serum IgM is persistently elevated, IgG is low, and IgA is absent. At 12 years of age, he developed immune complex disease after a viral infection, and developed severe renal disease, resulting in therapy-resistant hypertension. He died at the age of 25 , of cerebral hemorrhage. His older brother died at 5 mos old of $P$. carinii; serum IgM was elevated. The maternal grandparents were healthy and handled infections well.

Five of six brothers in Family 3 are affected with X-HIM. One boy died during infancy of $P$. carinii. The other four brothers have recurrent bacterial infections; two have neutropenia and all show elevated serum IgM, low IgG, and absent or low IgA. The mother and five maternal aunts are asymptomatic. Together, the five maternal aunts have 16 boys and 11 girls, all of whom are healthy. The only maternal uncle and the maternal grandmother are healthy.

Isolation and characterization of $g$ p 39 cDNAs. PBMCs were isolated from heparinized whole blood by centrifugation over lymphocyte separation medium (Organon Teknika Corp., Durham, NC). Cells were washed twice in RPMI 1640 and cultured under standard conditions $\left(37^{\circ} \mathrm{C}, 6 \% \mathrm{CO}_{2}\right)$ in RPMI 1640 containing $10 \%$ fetal calf serum (HyClone Laboratories), $100 \mathrm{U} / \mathrm{ml}$ penicillin and $100 \mu \mathrm{g} / \mathrm{ml}$ streptomycin. Cells were activated in the presence of PMA $(10 \mathrm{ng} / \mathrm{ml})$ and ionomycin $(1 \mu \mathrm{g} / \mathrm{ml})$ for $8 \mathrm{~h} .10^{7}$ cells were pelleted and immediately lysed in $0.5 \mathrm{ml}$ lysis buffer ( $4 \mathrm{M}$ guanidinium thiocyanate, $25 \mathrm{mM}$ sodium citrate $\mathrm{pH} \mathrm{7,1 \%} \mathrm{Sarkosyl} \mathrm{and} 100 \cdot \mathrm{mM}$ 2-mercaptoethanol). To the lysate was added $50 \mu \mathrm{l} 2 \mathrm{M}$ sodium acetate $\mathrm{pH} 4,0.5 \mathrm{ml}$ water-saturated phenol and $200 \mu \mathrm{l}$ chloroform. The mixture was vortexed and centrifuged and the aqueous layer transferred to a new tube. RNA was precipitated by the addition of an equal volume of isopropanol followed by incubation on ice for $1 \mathrm{~h}$. After centrifugation, pellets were washed one time with $70 \%$ ethanol, dried and resuspended in $30 \mu \mathrm{l}$ RNAase-free water. Concentration of RNA was measured by UV absorbance. $5 \mu \mathrm{g}$ total RNA was incubated with $2.5 \mu \mathrm{g}$ oligo(dT) 15 in $20 \mu \mathrm{l}$ at $70^{\circ} \mathrm{C}$ for $5 \mathrm{~min}$. On ice, remaining reaction components were added to a final volume of $50 \mu \mathrm{l}(50 \mathrm{mM}$ Tris [pH 8.8 at room temperature] $50 \mathrm{mM}$ $\mathrm{KCl}, 6 \mathrm{mM} \mathrm{MgCl}_{2}, 0.25 \mathrm{mM}$ dNTP, $10 \mathrm{mM}$ dithiothreitol, $8 \mathrm{mM}$ sodium pyrophosphate, 40 U RNAsin RNAase inhibitor [Promega, Madison, WI], $108 \mathrm{U}$ avian myeloblastosis virus reverse transcriptase (Life Sciences Inc., St. Petersburg, FL). Reactions were incubated at $42^{\circ} \mathrm{C}$ for $3.5 \mathrm{~h}$, then heated to $100^{\circ} \mathrm{C}$ for $10 \mathrm{~min}$, and placed on ice. PCRs were performed using Pfu polymerase (Stratagene, La Jolla, CA) or Taq polymerase (Perkin-Elmer Corp., Norwalk, CT) according to the manufacturers recommendations using oligonucleotide primers at the $5^{\prime}$ and $3^{\prime}$ ends of the coding region as previously described (6). As a template, 0.1 or $1 \mu \mathrm{l}$ of the cDNA reaction mixture was used. PCR products from affected males were sequenced directly following asymmetric PCR as described previously (6). PCR products obtained from females and unaffected males were cloned into a CDM8 vector and sequenced by dideoxy sequencing using Sequenase (United States Biochemical Corp., Cleveland, $\mathrm{OH}$ ). PCR products from members of family 3 or a normal control were used as templates in PCR reactions using primers flanking the deleted region. Primers were $5^{\prime}$-ATAATGTTAAACAAAGCGG-3' and 5'-GGACTTTAGGCAGAGGCTGGC-3'. PCR products were separated on a standard $2 \%$ agarose gel. For all PCRs performed, control reactions were included to which no template DNA had been added to verify the absence of contaminating DNA.

Two-color cell staining. PBMCs were washed twice in RPMI 1640 and resuspended to a final density of $1.5 \times 10^{7}$ cells $/ \mathrm{ml}$. Monoclonal antibodies 1F5 (anti-CD20) and G10-1 (anti-CD8) were added to a final concentration of $10 \mu \mathrm{g} / \mathrm{ml}$ and incubated on ice for $45 \mathrm{~min}$. Rabbit complement (Pel-Freeze Biologicals, Rogers, AR) was added and the mixture incubated at $37^{\circ} \mathrm{C}$ for $40 \mathrm{~min}$. Cells were washed twice in Iscoves medium and resuspended at a density of $2 \times 10^{7}$ cells $/ \mathrm{ml}$. An equal volume of $0.5 \mathrm{mM}$ Leu-Leu-OMe (Sigma Chemical Co., St. Louis, $\mathrm{MO}$ ) was added and cells incubated at room temperature for 15 minutes to remove monocytes and remaining NK cells and cytotoxic T lymphocytes (23). Cells were diluted with serum-free Iscoves medium, centrifuged $15 \mathrm{~min}$ at $1,400 \mathrm{rpm}$, and washed once more with serum-free Iscoves. Cells were resuspended in RPMI 1640 containing $10 \%$ fetal calf serum (Hyclone Laboratories, Logan, UT), $100 \mathrm{U} / \mathrm{ml}$ penicillin and $100 \mu \mathrm{g} / \mathrm{ml}$ streptomycin and cultured overnight under standard conditions. Cells were activated by the addition of PMA $(10 \mathrm{ng} / \mathrm{ml})$ and ionomycin $(1 \mu \mathrm{g} / \mathrm{ml})$. After $8 \mathrm{~h}$, cells were washed once with staining media (RPMI 1460 containing $2 \%$ fetal calf serum and $0.1 \% \mathrm{NaN}_{3}$ ). $1-5 \times 10^{5}$ cells per sample were stained on ice. Antibodies used were PE-conjugated anti-CD3 and anti-CD69 and FITC-conjugated anti-CD4 (Becton Dickinson, Mountain View, CA), PE-conjugated anti-Mac 1 (Boehringer Mannheim, Indianapolis, IN), FITC-conjugated B43 (antiCD19) (24), CD40-Ig (prepared as previously described) (6), and FITCconjugated goat anti-human Ig (Tago, Inc., Burlingame, CA).

\section{Results}

Pedigree analysis of families with HIGMI. As previously reported, the index case (C.D.) of Family 1 (Fig. $1 A$ ) has two point mutations, at positions 405 and 407 of the gp39 cDNA, which result in substitution of two amino acids and the inability of the mutated gp39 to bind to its ligand CD40, and a silent polymorphism at position 169 as compared with the original gp39 sequence $(6,15)$. DNA sequencing of multiple independent cDNA clones encoding gp39 from members of Family 1 indicated that both C.D.'s mother (K.H.) and sister (D.R.) are carriers of HIGM1 and express genes corresponding to the wild type and the defective gp39, while the maternal grandmother (W.H.) expresses only the wild-type gene and is not a carrier. For K.H., 9 of 12 independent gp39 cDNA clones encoded the wild type sequence, while for D.R., only 4 of 14 independent gp39 cDNA clones were wild type. In both instances the defective gene carried the gp39 polymorphism at position 169. DNA sequencing analysis of the maternal grandmother showed that she carries two wild type gp39 genes, one with the polymorphism of C.D. (10 of 18 independent cDNA clones) and one without (8 of 18 independent cDNA clones). Similar analysis of the cDNAs encoding gp39 from the maternal grandfather indicated that he carries a gp39 gene which contains the polymorphism (4 of 4 independent cDNA clones). These data suggest that the mother inherited the polymorphic allele from her father and the defect is a paternally derived de novo mutation arising in the mother, K.H. 


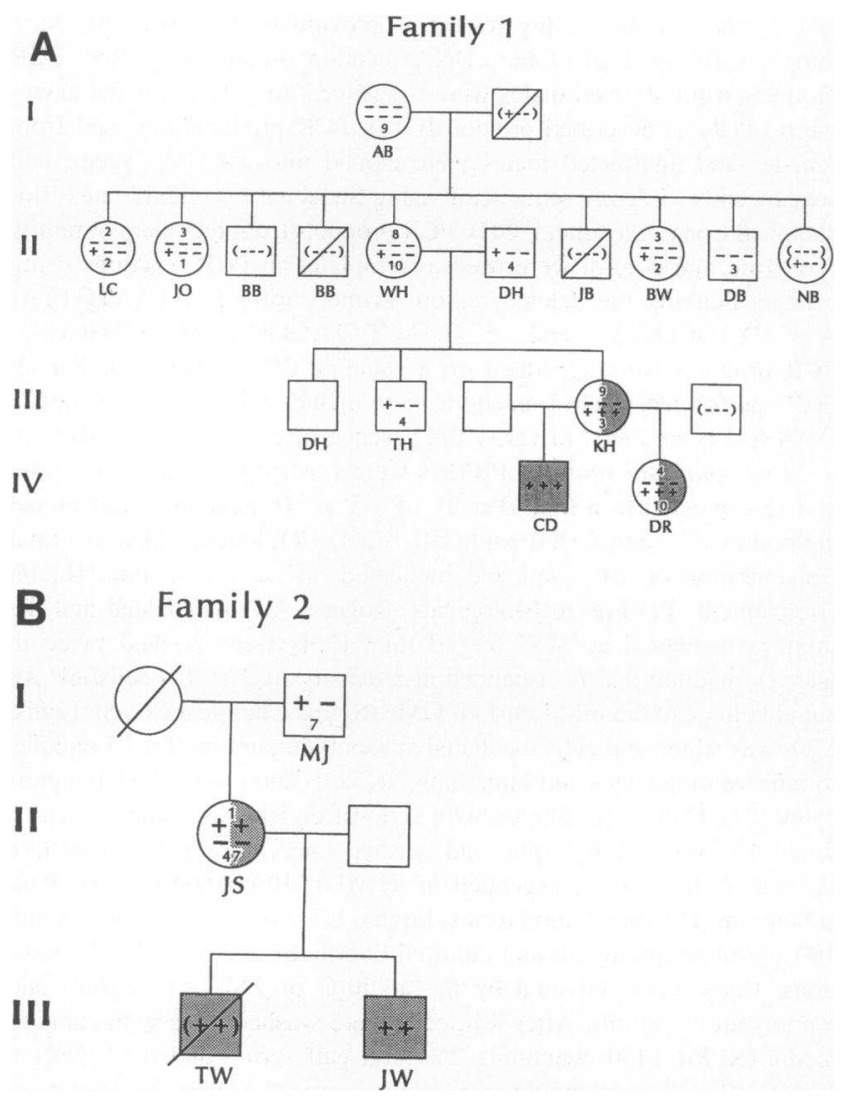

Figure 1. Pedigrees of two families of HIGM1. The notation of + and - refers to the mutations relative to the original gp39 sequence in sequential order; The first symbol indicates the presence $(+)$ or absence $(-)$ of the silent polymorphism at position 169 found in both families. Numbers given refer to the number of clones identified with the given sequence. $(A)$ Family 1 . The second and third symbols refer to the presence $(+)$ or absence $(-)$ of the mutations at positions 405 and 407 that result in the defect in the index case CD. (B) Family 2 . The second symbol refers to the presence $(+)$ or absence $(-)$ of the mutation at position 724 that results in the defect in the index case J.W.

The index case of Family 2, J.W., has a point mutation at position 724 resulting in a single amino acid substitution, and the same silent polymorphism at position 169 as found in C.D. (15). J.W.'s mother, J.S., is an obligate carrier having two affected male offspring (Fig. 1 B). Sequencing of gp39 cDNAs derived from mRNA isolated from in vitro stimulated PBMCs from J.S. demonstrated the presence of both alleles, the wild type and mutant, and the polymorphism at position 169 was found on the mutant allele. The low frequency of the mutant clones suggested that her $\mathrm{T}$ cells predominantly express the wild type gp39 gene (47 of 48 independent cDNA clones were wild type). J.W.'s maternal grandfather, M.J., carries a gene which contains the polymorphism at position 169 (7 of 7 independent clones). This suggests that the defect in this family is also a paternally derived de novo mutation. The maternal grandmother was not available for analysis.

Using PCR and DNA sequencing, we have identified the gp39 defect in a third family (Family 3, Fig. $2 A$ ). In this family, the mutation consists of a 63-base pair deletion that results in an inframe deletion of 21 amino acids within the TNF homologous extracellular domain of gp39 (Fig. 2 B). This mutation is the

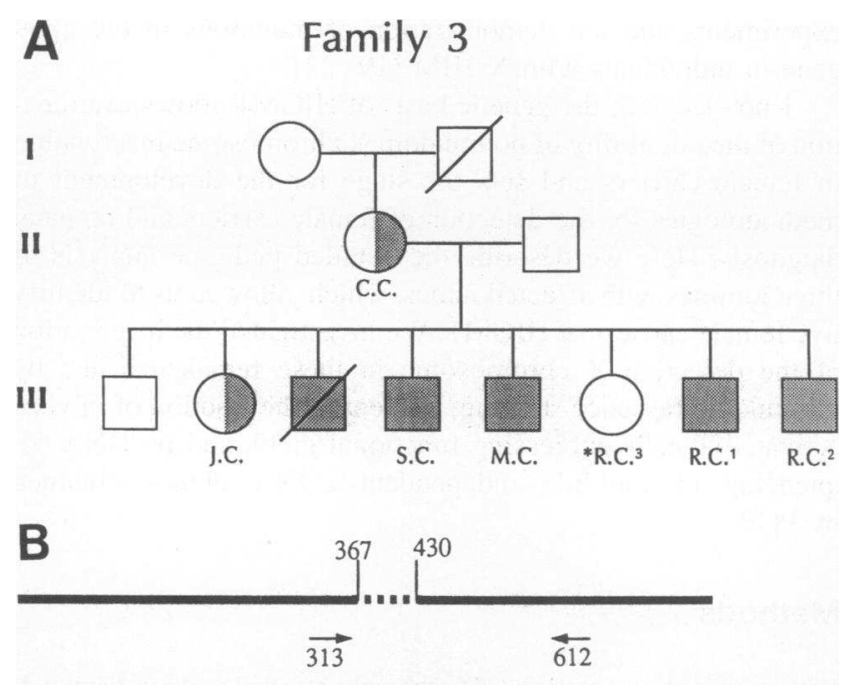

PCR products: normal 299 mutant 237

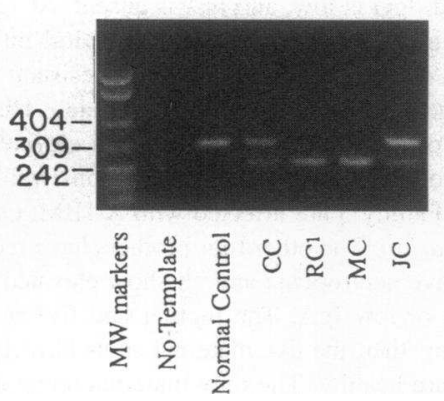

Figure 2. (A) Pedigree of Family 3. Carrier status of R.C. ${ }^{3}$ is not reported at the family's request. $(B)$ Schematic representation of the location of the deletion resulting in the defect in Family 3. PCR analysis of cDNA obtained from four family members using primers at positions 313 and 612.

same defect previously reported in an unrelated case (21). The large deletion allowed the use of a PCR-based approach for the identification of affected males and female carriers in this family. PCR reactions of cDNA derived from the activated PBMC of the affected males yielded fragments significantly smaller than those obtained for the normal control and of the size expected based on the 63-bp deletion. A similar analysis of the mother, C.C., an obligate carrier, and one daughter, J.C., revealed two gp39 DNA fragments consistent with the presence of a wild-type and a mutant gene (Fig. $2 \mathrm{~B}$ ). The carrier status of the second daughter, R.C. ${ }^{3}$, is not described at the family's request. This PCR based approach does not permit an evaluation of which gene, wild type or defective, is preferentially expressed.

Cell surface expression of functional gp39 by activated $T$ cells from female carriers. The DNA sequencing data described above indicate that $\mathrm{T}$ cells in which the normal $\mathrm{X}$ chromosome is active are not preferentially selected in female carriers of $\mathrm{X}$-HIM. To determine if the proportion of activated $\mathrm{T}$ cells 


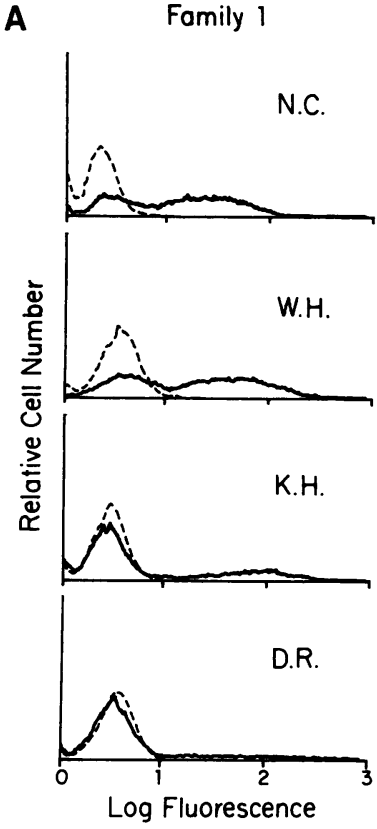

B

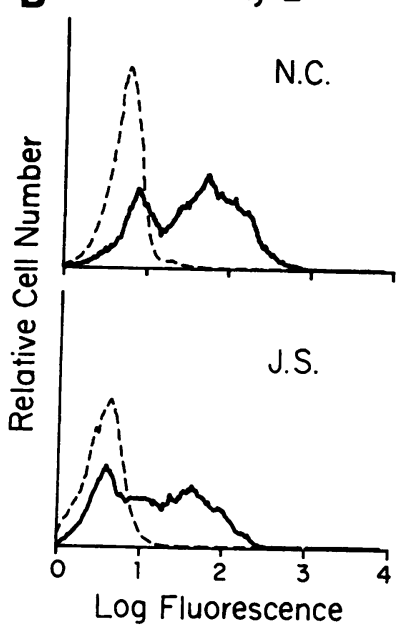

Figure 3. Flow cytometry analysis of activated PBMC stained with CD40Ig to detect the proportion of cells expressing functional gp39. (A) Family 1. K.H. and D.R. are carriers of HIGM. (B) Family 2. J.S. is a carrier of HIGM.

expressing functional gp39 mirrored the DNA sequencing data, PBMCs isolated from female carriers were activated in vitro and examined for the expression of functional gp39 using CD40-Ig and flow cytometry. Both female carriers in Family 1 (K.H. and D.R.) had only a small percentage of the PBMC expressing functional gp39 (23 and 12\%, respectively, as compared with $63 \%$ in the normal control, Fig. $3 \mathrm{~A}$ ). The single female carrier of Family 2 (J.S.) had numbers of cells expressing functional gp39 that were indistinguishable from normal controls (Fig. 3 $B$ ). In Family 3, activated PBMC from the two family members studied (C.C. and J.C.) expressed the mutant gp39 gene at an intermediate level (data not shown).

Effect of heterozygosity on serum Ig levels. Levels of Ig in the serum of the HIGM1 female carriers were analyzed (Table I). Values of serum IgM, IgG, IgA, or IgE for the female carriers were all within the normal range, with the exception of slightly elevated IgM levels for C.C. and low IgA levels seen for D.R. As IgA deficiency is common and is not seen in the other carriers, the low IgA levels seen for D.R. are expected to be unrelated to her status as an HIGM1 carrier.

Detection of female carriers of HIGMI. Because of the random inactivation of the $\mathrm{X}$ chromosome in female carriers of HIGM1, analysis of CD40-Ig binding to activated PBMCs may provide sufficient information for a definitive diagnosis of a carrier state. In cases where the wild-type gene is predominantly

Table I. Serum Ig Levels ( $\mathrm{mg} / \mathrm{dL}$ ) of Female Carriers of HIGM

\begin{tabular}{lcccr}
\hline \multicolumn{1}{c}{ Patient } & IgA & IgG & IgM & IgE \\
\hline J.S. & 292 & 1060 & 157 & 36 \\
K.H. & 124 & 766 & 254 & 9 \\
D.R. & 10 & 1520 & 233 & 14 \\
C.C. & 393 & 1420 & 373 & 238 \\
J.C. & 209 & 1350 & 318 & 26 \\
Normal range & $80-500$ & $725-1750$ & $40-350$ & $0-300$ \\
& & & & \\
\hline
\end{tabular}

expressed, it was not possible to detect the slight reduction in staining with CD40-Ig due to the expression of defective gp39 (Fig. $3 \mathrm{~B}$ ). In an effort to develop methods which could better detect female carriers, we isolated subpopulations of cells and analyzed the expression of gp39 after activation. Only 20-30\% of the total $\mathrm{CD}^{+}$population express gp39 (data not shown). However, greater than $90 \%$ of $\mathrm{CD}^{+} \mathrm{T}$ cells are positive for staining with CD40-Ig. To use this population, $\mathrm{CD}^{+} \mathrm{T}$ cells were isolated from normal donors and from female carriers from Families 1, 2, and 3 by complement and Leu-Leu-OMe depletion. These cells were then activated in vitro, stained with CD40-Ig and either anti-CD69, a marker of activation, or anti$\mathrm{CD} 3 \mathrm{mAb}$ and analyzed by flow cytometry. Physical isolation of $\mathrm{CD}^{+}$cells was necessary since CD4 expression is downregulated after $\mathrm{T}$ cell activation. Two color immunofluorescence studies of activated $\mathrm{CD}^{+} \mathrm{T}$ cells obtained from unaffected individuals showed cells which are $\mathrm{CD} 9^{+}$and $\mathrm{CD}^{+}$are also gp39 $9^{+}$(Fig. 4 and data not shown; $93 \%$ of $\mathrm{CD}^{+}$cells and $91 \%$ of $\mathrm{CD} 9^{+}$cells are gp $\left.39^{+}\right)$. In contrast, activated $\mathrm{CD} 4^{+} \mathrm{T}$ cells isolated from female carriers from Families 1 and 3 showed a significant population of cells which are gp $39^{-}$and $\mathrm{CD}^{+}$and gp39- and $\mathrm{CD}^{-} 9^{+}$. (Of $\mathrm{CD}^{+}$cells, 68, 65, 51, 33\% are gp39for K.H., D.R., C.C., and J.C., respectively; Of $\mathrm{CD}^{+} 9^{+}$cells, $66,63,57,38 \%$, are gp39-). However, for the carrier J.S., no significant difference from the normal control could be detected (Fig. $4 ; 73 \%$ of $\mathrm{CD}^{+}$cells and $81 \%$ of $\mathrm{CD} 69^{+}$cells are gp $39^{+}$).

\section{Discussion}

The subject of chromosomal inactivation in HIGM1 has been controversial. Reports showing preferential inactivation of the mutated $\mathrm{X}$ chromosome in lymphocytes of female carriers as well as reports demonstrating a random pattern of $\mathrm{X}$ chromosome inactivation in obligate carriers have appeared in the literature $(1,25,26)$. These conflicting reports may be due to the heterogeneity of the hyper IgM syndrome. The molecular characterization of HIGM1, demonstrating that mutations in the T 


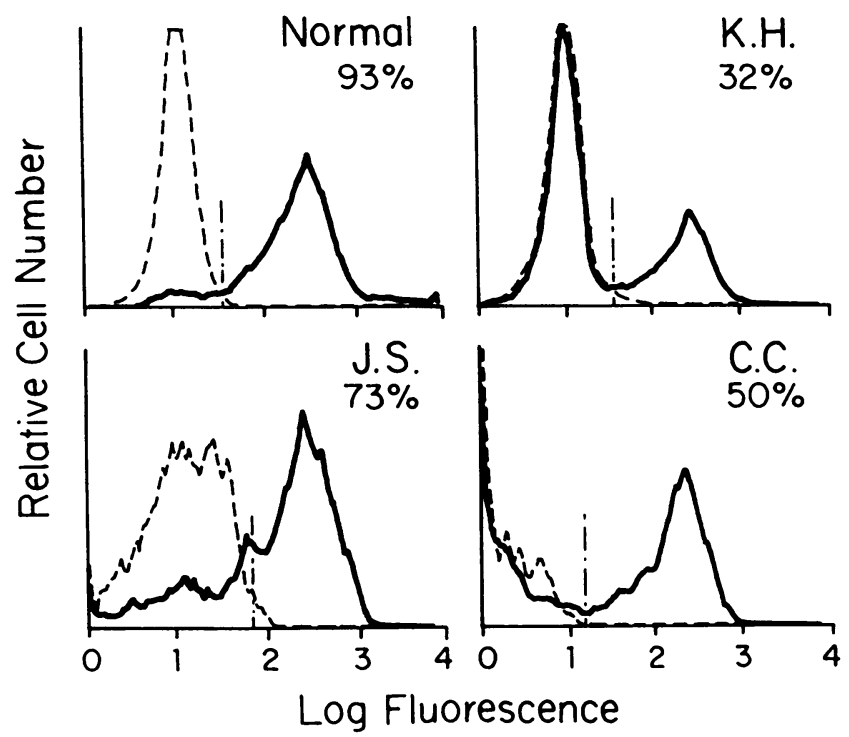

Figure 4. Flow cytometry analysis of activated $\mathrm{CD} 4^{+} \mathrm{T}$ cells stained with anti-CD3 and CD40-Ig in a two-color immunofluorescence study. Displayed is the staining with CD40-Ig of the population that was $\mathrm{CD}^{+}$.

cell surface protein gp39 are the basis for the HIGM1 defect, has allowed the reexamination of the pattern of $\mathrm{X}$ chromosome inactivation in the lymphocytes of female carriers of HIGM1. Using nucleic acid sequencing, PCR analysis, and receptor binding studies we have obtained detailed family pedigrees of three affected families. This has allowed us to identify a number of female carriers of the defective gene. Messenger RNA encoding gp39 was isolated from the in vitro activated PBMC of three female carriers from two different families and used to prepare cDNA. Multiple independent cDNA clones encoding gp39 from each carrier were sequenced. These experiments indicated that the pattern of $\mathrm{X}$ chromosome inactivation in the $\mathrm{T}$ cells from these female carriers was quite heterogeneous. We also examined the levels of functional gp39 protein expressed on the surface of the in vitro activated $\mathrm{T}$ cells obtained from female carriers from these two families and found that the levels of functional gp39 correlated very well with the number of cDNA clones encoding wild-type gp39. A third family with five affected males was also analyzed. DNA sequencing revealed that the mutation responsible for the defect in this family was a 21 amino acid deletion in the extracellular domain of gp39. This large deletion allowed the development of a PCR based method for the rapid detection of the mutation in other family members. Although this method does not allow a determination of the degree of skewing of the $\mathrm{X}$ chromosome inactivation, it allowed the facile identification of female carriers. Among the family members studied, two female carriers were identified. Examination of the $T$ cells of these female carriers showed that they express the normal and the mutated gene at approximately equal levels. These observations support the previous reports which suggest that in lymphocytes of female carriers there is no preferential selection for $\mathrm{T}$ cells in which the normal $\mathrm{X}$ chromosome is active.

Because of the random inactivation of the $\mathrm{X}$ chromosome carrying the defect, this could not be used to detect female carriers as has been suggested for detection of carriers of XLA, XSCID and Wiskott-Aldrich syndrome (27-29). As an alterna- tive, we wished to determine if a simple antibody based immunofluorescence assay could be developed for the detection of female carriers of HIGM1. The heterogeneity of obligate carriers in terms of the proportion of cells expressing the defective gp39 indicated that examining the binding of CD40-Ig to activated PBMCs may not be sufficient to distinguish carriers from noncarriers. To increase the sensitivity of the assay in an effort to detect low numbers of cells that express defective gp 39, we isolated $\mathrm{CD}^{+} \mathrm{T}$ cells, activated the cells in vitro and performed two color immunofluorescence assays using CD40-Ig and monoclonal antibodies against either the $\mathrm{T}$ cell marker CD3 or the lymphocyte activation marker CD69. This manipulation identified a subpopulation of $\mathrm{T}$ cells, $90 \%$ of which express gp39 in unaffected individuals. The female carriers Lyonized towards expression of the defective gp39 have a substantial population of $\mathrm{CD} 69^{+} / \mathrm{gp} 39^{-}$and $\mathrm{CD}^{+} / \mathrm{gp} 39^{-}$cells when compared to the normal controls. However, there is no advantage gained using this method in the ability to detect carriers in which the wild type gp39 is predominant, as demonstrated by the staining of $\mathrm{CD}^{+}$cells obtained from the carrier J.S.

The pattern of $\mathrm{X}$ chromosome inactivation and the clinical history of female carriers of X-linked immunodeficiencies may provide important information on the pathobiology of the disease and on the role of the gene product in the immune response. Extreme Lyonization may result in the phenotypic expression of an X-linked disease in a female carrier as evidenced by cases of hemophilia A, Wiskott-Aldrich syndrome and Duchenne muscular dystrophy observed in females (30-33). In the case of HIGM1, female carriers are asymptomatic and serum levels of immunoglobulins are within normal ranges, despite low numbers of $\mathrm{T}$ cells expressing gp39 $(<30 \%)$. This suggests symptoms of X-HIM are prevented by the presence of a small percentage of $\mathrm{T}$ cells able to express functional gp39. The role of the CD40/gp39 interaction in antibody production suggests this may be a potential therapeutic target in the treatment of antibody-mediated autoimmunity. The lack of a phenotypic effect of severely reduced levels of gp39 in female carriers of HIGM1 suggests that a very high level of inhibition of the gp39/CD40 interaction would be necessary for effectiveness. Preliminary in vivo studies have shown that onset of collagen induced arthritis could be prevented in a murine model by the administration of anti-gp39 monoclonal antibody (34). These results suggest that in the pathological condition, sufficient inhibition of the interaction can be achieved and that inhibitors of the gp39/ CD40 receptor ligand pair have therapeutic potential in the treatment of autoimmune diseases.

The pattern of $\mathrm{X}$ chromosome inactivation in female carriers of X-linked diseases may provide information on the role the affected gene plays in lymphocyte development. For example, the $\mathrm{X}$ chromosome carrying the defective gene is inactivated in B cells of carriers of XLA (35), and B and T cells of carriers of X-linked SCID (29). This unilateral pattern of X chromosome inactivation reflects the disadvantages conferred on the cells that express the defective gene during differentiation and proliferation. Indirect evidence has implicated the gp39/CD40 interaction in T cell development. CD40 is expressed by thymic epithelial cells and anti-CD40 mAb in the presence of INF- $\gamma$ or IL-1 triggers the release of GM-CSF (12). However, in vitro activated thymocytes did not bind to CD40-Ig suggesting that they lack expression of gp39 (C. P. Edwards and C. B. Wilson, personal communication). Although additional experiments are needed to elucidate the role, if any, of gp39 in T cell develop- 
ment, the lack of preferential inactivation of the mutated $\mathrm{X}$ chromosome in the $T$ cells of female carriers of HIGM1 suggests that expression of gp39 during $\mathrm{T}$ cell ontogeny is not critical for $\mathrm{T}$ cell development.

The identification of the defect in the X-HIM syndrome as a defect in the gene encoding gp39 allows a comparison of known roles of the receptor ligand pair with the clinical manifestations of the disease. The importance of the CD40 ligand/ receptor pair in the interaction between $B$ and $T$ cells has been suggested by in vitro experiments. Through the use of $\mathrm{mAb}$, stimulation of the CD40 receptor was found to induce B cell proliferation and isotype switching in the presence of an appropriate costimulus. The absence of isotype switching in the $\mathrm{X}$ HIM patients confirms this role of the gp39/CD40 ligand receptor pair. The recent identification of CD40 on the surface of monocytes, and the resulting cytokine induction when the receptor is engaged, demonstrates another role for the ligand pair (10). The increased frequency of $P$. carinii infection and malignancies, generally considered to be a consequence of a $\mathrm{T}$ cell defect, may be a result of the lack of monocyte-derived $\mathrm{T}$ cell stimulation. The neutropenia observed in some X-HIM patients may also be caused indirectly, by the absence of cytokines normally produced in response to CD40 stimulation, as there is no known direct role of gp39 in the ontogeny or maintenance of this cell population. A recent report has demonstrated that B cell apoptosis upon antigen stimulation is prevented by CD40 costimulation, suggesting a role for CD40 during the elimination of self reactive $B$ cells (36). In the absence of CD40 stimulation, all B cells might be expected to be eliminated. As the HIM patients have normal numbers of functionally active $B$ cells, a mechanism other than CD40/gp39 interaction must be available for the prevention of apoptosis.

\section{Acknowledgments}

We thank Dr: Andrew Peterson for critical review, Cora Jensen, and Wanda Losee for assistance with sample collection and transport and Debby Baxter for help in the preparation of this manuscript.

This work was supported in part by National Institutes of Health grants HD17427 (to H.D.Ochs), RR-37 (to the Clinical Research Center of the University of Washington) and AI13150 (to H. R. Hill), Department of Energy grant DE-F006-86-ER60409 (to A. Aruffo) and the Bristol-Myers Squibb Pharmaceutical Research Institute.

\section{References}

1. Notarangelo, L. D., M. Duse, and A. G. Ugazio. 1992. Immunodeficiency with hyper-IgM (HIM). Immunodefic. Rev. 3:101-122.

2. Clark, E. A., and J. A. Ledbetter. 1986. Activation of human B cells mediated through two distinct cell surface differentiation antigen, Bp35 and Bp50. Proc. Natl. Acad. Sci. USA. 83:4494-4498.

3. Ledbetter, J. A., G. Shu, M. Gallagher, and E. A. Clark. 1987. Augmentation of normal and malignant B cell proliferation by monoclonal antibody to the B cell-specific antigen BP50 (CDW40). J. Immunol. 138(3):788-794.

4. Noelle, R. J., R. Meenakshi, D. M. Shepherd, I. S. Stemenkovic, J. A. Ledbetter, and A. Aruffo. 1992. A 39-kDa protein on activated helper T cells binds CD40 and transduces the signal for cognate activation of B cells. Proc. Natl. Acad. Sci. USA. 89:6550-6554.

5. Armitage, R. J., W. C. Fanslow, L. Strockbine, T. A. Sato, K. N. Clifford, B. M. Macduff, D. M. Anderson, S. D. Gimpel, T. Davis-Smith, C. R. Maliszewski, E. A. Clark, C. A. Smith, K. H. Grabstein, D. Cosman, and M. K. Spriggs. 1992. Molecular and biological characterization of a murine ligand for CD40. Nature (Lond.). 357:80-82.

6. Hollenbaugh, D., L. S. Grosmaire, C. D. Kullas, N. J. Chalupny, S. BraeschAndersen, R. J. Noelle, I. Stamenkovic, J. A. Ledbetter, and A. Aruffo. 1992. The human T cell antigen gp39, a member of the TNF gene family, is a ligand for the CD40 receptor: expression of a soluble form of gp39 with B cell costimulatory activity. EMBO (Eur. Mol. Biol. Organ.) J. 11(12):4313-4321.

7. Spriggs, M. K., R. J. Armitage, L. Stockbine, K. N. Clifford, B. M. Macduff, T. A. Sato, C. R. Maliszewski, and W. C. Fanslow. 1992. Recombinant human CD40 ligand stimulates B cell proliferation and immunoglobulin E secretion. $J$. Exp. Med. 176:1543-1550.

8. Graf, D., U. Korthauer, H. W. Mages, G. Senger, and R. A. Kroczek. 1992. Cloning of TRAP, a ligand for CD40 on human T cells. Eur. J. Immunol. 22:3191 3194.

9. Stamenkovic, I., E. A. Clark, and B. Seed. 1989. A B-lymphocyte activation molecule related to the nerve growth factor receptor and induced by cytokines in carcinomas. EMBO (Eur. Mol. Biol. Organ.) J. 8:1403-1410.

10. Alderson, M. R., R. J. Armitage, T. W. Tough, L. Strockbine, W. C. Fanslow, and M. K. Spriggs. 1993. CD40 expression by human monocytes: Regulation by cytokines and activation of monocytes by the ligand CD40. J. Exp. Med. 178:669-674.

11. Young, L. S., C. W. Dawson, K. W. Brown, and A. B. Rickinson. 1989. Identification of a human epithelial cell surface protein sharing an epitope with the C3d/Epstein-Barr virus receptor molecule of B lymphocytes. Int. J. Cancer. 43(5):786-794.

12. Galy, A. H., and H. Spits. 1992. CD40 is functionally expressed on human thymic epithelial cells. J. Immunol. 149:775-782.

13. Paulie, S., B. Ehlin-Hendricksson, H. Mellstedt, H. Koho, H. Ben-Aissa, and P. Perlmann. 1985. Ap50 surface antigen restricted to human urinary bladder carcinomas and B lymphocytes. Cancer Immunol. Immunother. 20(1):23-28.

14. Banchereau, J., P. de Paoli, A. Valle, E. Garcia, and F. Rousset. 1991. Long-term human B cell lines dependent on interleukin-4 and antibody to CD40. Science (Wash. DC). 251:70-72.

15. Aruffo, A., M. Farrington, D. Hollenbaugh, X. Li, A. Milatovich, S. Nonoyama, J. Bajorath, L. S. Grosmaire, R. Stenkamp, M. Neubauer, R. L. Roberts, R. J. Noelle, J. A. Ledbetter, U. Francke, and H. D. Ochs. 1993. The CD40 ligand, gp39, is defective in activated $\mathrm{T}$ cells from patients with $\mathrm{X}$-linked hyper-IgM syndrome. Cell. 72:291-300.

16. Gordon, J., M. J. Millsum, G. Guy, and J. A. Ledbetter. 1988. Resting B lymphocytes can be triggered directly through the CDw40 (Bp50) antigen. A comparison with IL-4-mediated signaling. J. Immunol. 140:1425-1430.

17. Jabara, H. H., S. M. Fu, R. S. Geha, and D. Vercelli. 1990. CD40 and IgE: synergism between anti-CD40 monoclonal antibody and interleukin 4 in the induction of IgE synthesis by highly purified human B cell. J. Exp. Med. 172:1861-1864.

18. Zhang, K., E. A. Clark, and A. Saxon. 1991. CD40 stimulation provides an IFN independent and IL-4 dependent differentiation signal directly to human B cells for IgE production. J. Immunol. 146:1836-1842.

19. Allen, R. C., R. J. Armitage, M. E. Conley, H. Rosenblatt, N. A. Jenkins, N. G. Copeland, M. A. Bedell, S. Edelhoff, C. M. Disteche, D. K. Simoneaux, W. C. Fanslow, J. Belmont, and M. K. Spriggs. 1993. CD40 ligand gene defects responsible for X-linked hyper-IgM syndrome. Science (Wash. DC). 259:990993.

20. Korthauer, U., D. Graf, H. W. Mages, F. Briere, M. Padayachee, S Malcolm, A. G. Ugazio, L. D. Notarangelo, R. J. Levinsky, and R. A. Kroczek 1993. Defective expression of T-cell CD40 ligand causes X-linked immunodeficiency with hyper-IgM. Nature (Lond.). 361:539-541.

21. Di Santo, J. P., J. Y. Bonnefoy, J. F. Gauchat, A. Fischer, and G. de SaintBasile. 1993. CD40 ligand mutations in X-linked immunodeficiency with hyperIgM. Nature (Lond.). 361:541-543.

22. Fuleihan, R., N. Ramesh, R. Loh, H. Jabara, R. S. Rosen, T. Chatila, S. M. Fu, I. Stamenkovic, and R. S. Geha. 1993. Defective expression of the CD40 ligand in $\mathrm{X}$ chromosome-linked immunoglobulin deficiency with normal or elevated IgM. Proc. Natl. Acad. Sci. USA. 90(6):2170-2173.

23. Thiele, D. L., and P. E. Lipsky. 1986. The immunosuppressive activity of L-leucyl-L-leucine methyl ester: selective ablation of cytotoxic lymphocytes and monocytes. J. Immunol. 136(3):1038-1048.

24. Uckun, F. M., W. Jaszcz, J. L. Ambrus, A. S. Fauci, K. Gajl-Peczalska C. W. Song, M. R. Wick, D. E. Myers, K. Waddick, and J. A. Ledbetter. 1988. Detailed studies on expression and function of CD19 surface determinant by using B43 monoclonal antibody and the clinical potential of anti-CD19 immunotoxins. Blood. 71(1):13-29.

25. Notarangelo, L. D., O. Parolini, A. Albertini, M. Duse, E. Mazzolari, A. Plebani, G. Camerino, and A. G. Ugazio. 1991. Analysis of X-chromosome inactivation in X-linked immunodeficiency with hyper-IgM (HIGM1): evidence for involvement of different hematopoietic cell lineages. Hum. Genet. 88:130134.

26. Hendriks, R. W., M. E. M. Kraakman, I. W. Craig, T. Espanol, and R. K. B. Schuurman. 1990. Evidence that in X-linked immunodeficiency with hyperimmunoglobulinemia $\mathbf{M}$ the intrinsic immunoglobulin heavy chain class switch mechanism is intact. Eur. J. Immunol. 20:2603-2608.

27. Miyashita, T., T. Iwata, S. Mizutani, S. Kamoshita, and N. Kobayashi. 1993. Carrier detection in agammaglobulinemia by $\mathrm{X}$ chromosome inactivation analysis. Acta. Paediatr. 34(3):267-272. 
28. Conley, M. E., and J. M. Puck. 1988. Carrier detection in typical and atypical X-linked agammaglobulinemia. J. Pediatr. 112(5):688-694.

29. Conley, M. E., A. Levoie, C. Briggs, P. Brown, C. Guerra, and J. M. Puck. 1988. Nonrandom X chromosome inactivation in B cells from carriers of $\mathrm{X}$ chromosome-linked severe combined immunodeficiency. Proc. Natl. Acad. Sci. USA. 85(9):3090-3094.

30. Matsushita, T., J. Takamatsu, K. Kagami, I. Takahashi, I. Sugiura, M Hamaguchi, T. Kamiya, and H. Saito. 1992. A female hemophilia A combined with hereditary coagulation factor XII deficiency: a case report. Am. J. Hematol. 39(2):137-141.

31. Ingerslev, J., M. Schwartz, L. U. Lamm, T. A. Kruse, A. Bukh, and S. Stenbjerg. 1989. Female haemophilia $\mathbf{A}$ in a family with seeming extreme bidirectional lyonization tendency: abnormal premature $\mathrm{X}$-chromosome inactivation? Clin. Genet. 35(1):41-48.

32. Notarangelo, L. D., O. Parolini, F. Locatelli, A. Lanfranchi, M. Marconi, L. Nespoli, A. Albertini, T. W. Craig, and A. G. Ugazio. 1991. Analysis of
$\mathrm{X}$-chromosome inactivation and presumptive expression of the Wiskott-Aldrich syndrome (WAS) gene in hematopoietic cell lineages of a thrombocytopenic carrier female of WAS. Hum. Genet. 88(2):237-241.

33. Richards, C. S., S. C. Watkins, E. P. Hoffman, N. R. Schneider, I. W. Milsark, K. S. Katz, J. D. Cook, L. M. Kunkel, and J. M. Cortada. 1990. Skewed $\mathrm{X}$ inactivation in a female $\mathrm{MZ}$ twin results in Duchenne muscular dystrophy. Am. J. Hum. Genet. 46(4):672-681.

34. Durie, F. H., R. A. Fava, T. M. Foy, A. Aruffo, J. A. Ledbetter, and R. J. Noelle. 1993. Prevention of collagen-induced arthritis with an antibody to gp39, the ligand for CD40. Science (Wash. DC). 261:1328-1330.

35. Schwaber, J., J. Payne, and R. Chen. 1988. B lymphocytes from X-linked agammaglobulinemia. Delayed expression of light chain and demonstration of Lyonization in carriers. J. Clin. Invest. 81:514-522.

36. Tsubata, T., J. Wu, and T. Honjo. 1993. B-cell apoptosis induced by antigen receptor crosslinking is blocked by a T-cell signal through CD40. Nature (Lond.). 364:645-648. 